\title{
EFEK MINYAK ATSIRI DAUN NILAM (Pogostemon cablin Benth) TERHADAP KADAR MDA TIKUS YANG DIPAPAR ASAP ROKOK
}

\author{
Reni Tangko, Winda Wardianti, Reka Safitri, Mirnawati Salampe \\ Sekolah Tinggi Ilmu Farmasi Makassar, Makassar, Indonesia
}

Kata Kunci :

Asap Rokok, Radikal

Bebas, Minyak Atsiri, Pogostemon cablin Benth

\begin{abstract}
ABSTRAK
Tujuan penelitian ini adalah untuk mengetahui aktivitas peredaman radikal bebas dari minyak atsiri daun nilam (Pogostemon cablin Benth.) yang dibuat dalam sediaan air spray melalui pengukuran parameter stress oksidatif (MDA) pada tikus yang dipapar asap rokok. Hewan yang digunakan dalam penelitian ini yaitu tikus (Rattus norvegicus) sebanyak 30 ekor, dibagi ke dalam 5 kelompok dimana setiap kelompok terdiri atas 6 ekor tikus. Kelompok 1 (kontrol sehat) diberikan aquadest selama 7 hari; Kelompok 2 (kontrol negatif) dipapar asap rokok; Kelompok 3 (kontrol positif) dipapar asap rokok dan diberikan vitamin C; Kelompok 4 dipapar asap rokok dan di semprotkan air spray; Kelompok 5 dipapar asap rokok terlebih dahulu, selanjutnya 10 menit setelah pemaparan asap rokok disemprotkan air spray. Perlakuan terhadap hewan uji dilakukan selama 7 hari dan hari ke delapan dilakukan pengambilan darah untuk pemeriksaan parameter MDA serum. Hasil penelitian menunjukkan bahwa kelompok tikus yang dipapar asap rokok dan disemprotkan spray minyak nilam memiliki kadar MDA serum yang lebih rendah dibandingkan kelompok kontrol negatif. Hal ini dapat disimpulkan bahwa senyawa volatile oil daun nilam berpotensi sebagai penangkal radikal bebas asap rokok di udara.
\end{abstract}

$\begin{array}{ll}\text { Masuk } & 24-06-2019 \\ \text { Revisi } & 05-11-2019 \\ \text { Diterima } & 19-11-2019\end{array}$

Korespondensi

\section{Reni Tangko}

renitangko455@gmail.com

Copyright

C 2019 Majalah Farmasi Farmakologi Fakultas

Farmasi - Makassar

Diterbitkan tanggal 19-11-2019

Dapat Diakses Daring Pada:

http://journal.unhas.ac.id /index.php/mff

\section{PENDAHULUAN}

Asap rokok terdiri atas dua bagian yaitu, mainstream (yang terhirup oleh perokok) dan sidestream (asap yang ke luar ke udara). Mainstream terdiri atas partikel padat (tar) dan fase gas (zat toksik, senyawa organik yang mudah menguap, VOC, radikal bebas, dll.). Asap sidestream dibagi dalam fase padat dan gas, mengandung konsentrasi tinggi senyawa beracun dan karsinogenik dan senyawa volatil dan semivolatil lainnya. Beberapa komponen dalam asap rokok yang bersifat radikal yaitu dalam bentuk anion superoksida $\left(\mathrm{O}_{2}{ }^{--}\right), \mathrm{H}_{2} \mathrm{O}_{2}$ dan radikal reaktif hidroksil (HO•), yang menyebabkan kerusakan oksidatif pada lipid membran sel, protein, enzim dan DNA. Perokok pasif (atau asap tembakau lingkungan, ETS) telah terbukti berbahaya bagi kesehatan non-perokok (1).

Beberapa upaya telah dilakukan selama ini untuk mengurangi dampak merugikan dari asap rokok, diantaranya adalah peraturan kawasan bebas asap rokok, upaya rehabilitasi pada orang-orang yang mengalami kecanduan merokok, penggunaan zatzat antioksidan untuk mencegah terjadinya kerusakan oksidatif di dalam tubuh misalnya konsumsi vitamin $\mathrm{A}$, vitamin $\mathrm{C}$, vitamin $\mathrm{E}$, dan beberapa antioksidan lainnya (2).

Akan tetapi, upaya tersebut sebagian besar hanya diperuntukkan kepada perokok aktif. Tingginya angka prevalensi bahaya asap rokok mendorong peneliti mencari suatu ide untuk meredam zat-zat berbahaya dalam asap rokok. Zat-zat berbahaya dalam asap rokok bersifat radikal bebas yang menyebabkan terjadinya kerusakan oksidatif di dalam tubuh. Oleh karena itu radikal bebas dapat diatasi menggunakan senyawa-senyawa yang bersifat antioksidan (penangkal radikal bebas).
Studi menunjukkan bahwa senyawa-senyawa terpenoid, fenolik, atau flavanoid memiliki aktivitas antioxidant atau dapat meredam radikal bebas (3).

Salah satu tanaman yang memiliki kandungan terpenoid yaitu nilam (Pogostemon cablin Benth.). Kandungan utama yang telah diisolasi dari daun nilam yaitu minyak esensial atau volatile oil (patchouli oil) (4). Penelitian menunjukkan bahwa patchouli oil memiliki aktivitas meredam radikal bebas sehingga mencegah terjadinya kematian sel dalam bentuk nekrosis dan apoptosis (5).

Kandungan senyawa volatile dalam daun nilam diharapkan memiliki potensi dalam meredam radikal bebas asap rokok di udara. Salah satu bentuk sediaan yang dapat digunakan pada senyawa volatile dan mudah digunakan yaitu air spray. Spray dapat menghantarkan senyawa ke udara yang mengandung asap rokok. Pengaplikasian sediaan air spray lebih diutamakan di dalam ruangan, sehingga udara dalam ruangan yang mengandung asap rokok dapat dinetralisir sebelum dihirup oleh perokok pasif.

Model penelitian yang dilakukan yaitu menggunakan hewan uji yang dipapar asap rokok dalam suatu ruangan (chamber) dan disemprotkan air spray yang berisi minyak atsiri daun nilam. Minyak atsiri tersebut dibuat dalam bentuk sediaan air spray. Parameter pemeriksaan untuk menentukan keberhasilan dari penelitian adalah indeks stress oksidatif dalam hal ini Malondialdehid (MDA).

MDA merupakan hasil akhir pada proses peroksidasi lipid yang bersifat mutagenik. Peroksidasi lipid terjadi karena reaksi antara radikal reaktif hidroksil (HO•) dengan komponen sel dalam hal ini unsaturated fatty acid 


\section{METODE PENELITIAN}

\section{Prosedur Kerja}

Formula Air Spray Minyak Atsiri Daun Nilam

Dilakukan dengan mencampurkan minyak nilam 80\% dengan pengaroma lemon $20 \%$.

\section{Penyiapan Hewan dan Pemberian Perlakuan}

Hewan yang digunakan dalam penelitian ini yaitu tikus (Rattus norvegicus) sebanyak 30 ekor, dibagi ke dalam 5 kelompok dimana setiap kelompok terdiri atas 6 ekor tikus. Kelompok 1 (kontrol sehat) diberikan aquadest selama 7 hari; Kelompok 2 (kontrol negatif) dipapar asap rokok; Kelompok 3 (kontrol positif) dipapar asap rokok dan diberikan vitamin C; Kelompok 4 dipapar asap rokok dan di semprotkan air spray; Kelompok 5 dipapar asap rokok terlebih dahulu, selanjutnya 10 menit setelah pemaparan asap rokok disemprotkan air spray. Perlakuan terhadap hewan uji dilakukan selama 7 hari dan hari ke delapan dilakukan pengambilan darah untuk pemeriksaan parameter MDA serum. Pemaparan asap rokok dilakukan di dalam kandang hewan yang telah dimodifikasi

\section{Pengumpulan Sampel Darah}

Setelah tujuh hari perlakuan, hari ke 8 dilakukan pengambilan darah tikus melalui vena lateralis. Darah yang dikumpulkan pada tabung vakutainer didiamkan pada suhu ruangan 15-30 menit selanjutnya sampel disentrifugasi dengan kecepatan $2000 \mathrm{rpm}$ selama 10 menit. Serum dipisahkan dari supernatant selanjutnya dilakukan pengukuran kadar MDA

\section{Pengukuran MDA Menggunakan Spektrofotometer}

Dibuat larutan standar 1000 ppm dengan cara dipipet larutan standar 1,1,3,3-tetrametoksipropana (TMP) $10 \mu \mathrm{l}$ ke dalam labu tentukur $10 \mathrm{ml}$ dan dilarutkan dengan PBS pH 7.4, TCA $10 \%$ dan TBA $1 \%$ dengan perbandingan 0,5: 1:1. Kemudian dibuat larutan standar 100 ppm dan 5 ppm dari larutan standar 1000 ppm. Larutan standar 5 ppm dijadikan larutan stok, selanjutnya dibuat beberapa seri konsentrasi standar $(0,005 ; 0,1 ; 0,15 ; 0,2 ; 0,25 ; 0,30 \mathrm{ppm})$.

Semua seri konsentrasi standar dipanaskan selama 20 menit pada suhu $95^{\circ} \mathrm{C}$ menggunakan waterbath. Kemudian didinginkan pada suhu kamar dan diukur absorbansinya menggunakan spektrofotometer UV-VIS pada Panjang gelombang $532 \mathrm{~nm}$. Sebanyak $500 \mu \mathrm{l}$ serum dimasukkan ke dalam tabung sentrifuge yang telah dilabel. Pada Masingmasing tabung ditambahkan TBA $1 \%$ 0,5 ml dan TCA 10\% 0,5 $\mathrm{ml}$. Tabung berisi larutan kemudian dipanaskan dalam waterbath pada suhu $95^{\circ} \mathrm{C}$ selama 20 menit. Selanjutnya disentrifugasi pada kecepatan $7000 \mathrm{rpm}$ selama 10 menit. Supernatan yang diperoleh diukur absorbansinya menggunakan spektrofotometer UV-VIS pada panjang gelombang $535 \mathrm{~nm}$.

\section{Analisis Data}

Data hasil pengukuran MDA serum diolah secara statistik menggunakan metode ANOVA yang akan dilanjutkan dengan uji post-hoc yang sesuai.

\section{HASIL DAN PEMBAHASAN}

Hasil pengukuran kadar MDA pada Gambar 1 menunjukkan bahwa kontrol negatif memiliki kadar MDA lebih tinggi dibandingkan kelompok perlakuan lainnya. Walaupun analisis statistik menggunakan metode ANOVA menunjukkan tidak ada perbedaan bermakna antar semua kelompok perlakuan, kadar MDA pada kelompok tikus yang mendapatkan pemaparan asap rokok dan spray minyak nilam lebih rendah dibandingkan kelompok kontrol negatif.

\begin{tabular}{lcc}
$\begin{array}{l}\text { Tabel 1. Hasil Pengukuran Kadar MDA Serum Tikus Setelah Perlakuan } \\
\text { Selama 7 Hari }\end{array}$ \\
\hline No & Kelompok & $\begin{array}{c}\text { Rata-rata Kadar MDA } \\
(\boldsymbol{\mu g} / \mathbf{m l}) \pm \text { SD }\end{array}$ \\
\hline 1 & Kontrol Sehat & $0.047 \pm 0.0065$ \\
2 & Kontrol Negatif & $0.17 \pm 0.0349$ \\
3 & Kontrol Positif (Vitamin C) & $0.103 \pm 0.0521$ \\
4 & Perlakuan 1 & $0.101 \pm 0.0312$ \\
5 & Perlakuan 2 & $0.125 \pm 0.0603$ \\
\hline
\end{tabular}

Keterangan: Kontrol negatif (mendapatkan pemaparan asap rokok), Kontrol positif (diberikan vitamin C sebelum pemaparan asap rokok), Perlakuan 1 (disemprotkan spray minyak atsiri bersamaan pemaparan asap rokok), Perlakuan 2 (Pemaparan asap rokok terlebih dahulu kemudian disemprotkan spray minyak atsiri)

Kadar MDA pada kelompok tikus yang dipapar asap rokok lebih tinggi dibandingkan kelompok tikus normal (tanpa pemaparan asap rokok) (Gambar 1). Hal ini disebabkan oleh kandungan zat- zat toksik, bersifat karsinogenik dan mutagenik dalam bentuk radikal bebas stabil dan tidak stabil, serta ROS dalam bentuk partikel dan fase gas yang berpotensi menyebabkan kerusakan oksidatif jika terhirup masuk ke dalam saluran pernafasan (1).

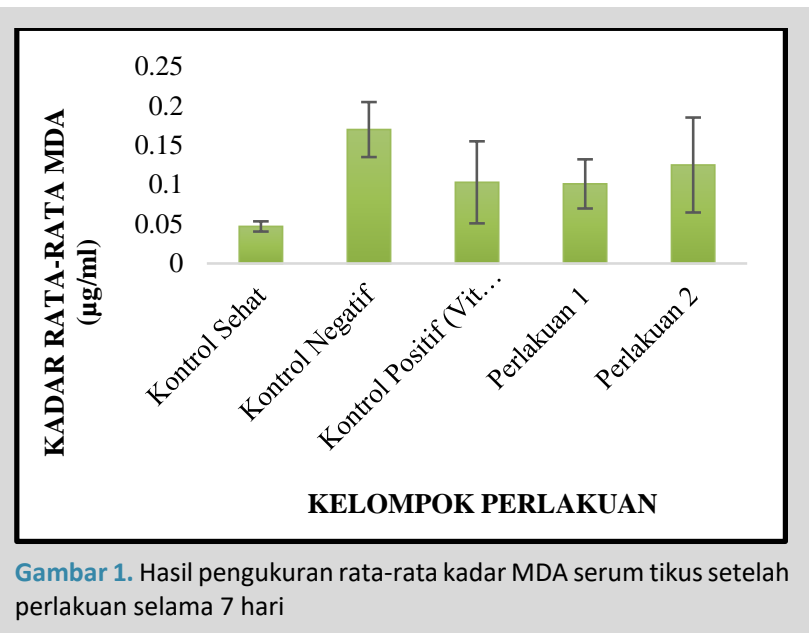

Kerusakan oksidatif atau Stress oksidatif terjadi ketika radikal bebas melampaui kapasitas antioksidan yang dapat ditandai dengan peningkatan kadar malondialdehid (MDA). MDA merupakan hasil akhir pada proses peroksidasi lipid yang bersifat mutagenik. Peroksidasi lipid terjadi karena reaksi antara radikal reaktif hidroksil (HO•) dengan komponen sel dalam hal ini unsaturated fatty acid (6).

Kadar MDA pada kelompok tikus yang mendapatkan pemaparan asap rokok dan spray minyak nilam (Perlakuan 1) lebih rendah dibandingkan kelompok negatif. Hal ini dapat disebabkan oleh kandungan senyawa aktif dalam minyak nilam yang memiliki aktivitas antioksidan. Antioksidan merupakan senyawa yang dapat meredam radikal bebas dengan beberapa mekanisme yaitu, secara langsung bereaksi dengan radikal bebas, menghambat aktivitas dan ekspresi sejumlah enzim yang menghasilkan radikal, meningkatkan aktivitas dan ekspresi dari antioksidan endongen (intracellular antioxidant enzymes), serta membentuk ikatan khelat dengan ion metal yang berperan dalam proses pembentukan radikal (7). 
Mekanisme antioksidan dari senyawa aktif minyak nilam dalam meredam radikal asap rokok di udara kemungkinan melalui proses reaksi langsung dengan radikal. Radikal bebas

Komponen utama dalam daun nilam yang telah diisolasi yaitu minyak atsiri atau volatile oil yang sering disebut patchouli oil. Penelitian menunjukkan bahwa patchouli oil memiliki aktivitas meredam radikal bebas sehingga mencegah terjadinya kematian sel dalam bentuk nekrosis dan apoptosis (5). Patchouli oil terdiri atas senyawa sesquiterpene utamanya patchouli alcohol (patchoulol), tricyclic sesquiterpene, caryophyllene, pogostol, $\alpha-, \beta-, \gamma-$ and $\delta$ patchoulene, seychellene, cycloseychellene, $\alpha$ - and $\beta$-bulnesene, $\alpha$ - and $\beta$-guaiene and norpatchoulenol. Aktivitas biologi dari Patchouli oil dikaitkan dengan senyawa pogostone, patchoulol, $\alpha$ - and $\beta$-patchoulene (4).

Studi lain menunjukkan bahwa tanaman ini memiliki kandungan senyawa diantaranya, monoterpenoid, triterpenoid, seskuiterpenoid, pitosterol, flavonoid, organik asam, lignin, glikosida, alkohol dan aldehida. Senyawasenyawa tersebut terdapat dalam dua bentuk yaitu senyawa volatile dan non-volatil. Studi menunjukkan bahwa senyawasenyawa terpenoid, fenolik, atau flavanoid memiliki aktivitas antioxidant atau dapat meredam radikal bebas (3).

\section{KESIMPULAN}

Kadar MDA pada kelompok tikus yang mendapatkan pemaparan asap rokok dan spray minyak nilam lebih rendah dibandingkan kelompok negatif. Berdasarkan hal tersebut, dapat disimpulkan bahwa senyawa volatile oil daun nilam berpotensi sebagai penangkal radikal bebas asap rokok di udara. mengoksidasi senyawa aktif sehingga terjadi pelepasan satu atom hidrogen atau satu elektron. Hal ini menyebabkan radikal bebas menjadi stabil atau tidak reaktif lagi.

\section{DAFTAR PUSTAKA}

1. Valavanidis, A., Vlachogianni, T. and Fiotakis, K. (2009) 'Tobacco Smoke : Involvement of Reactive Oxygen Species and Stable Free Radicals in Mechanisms of Oxidative Damage, Carcinogenesis and Synergistic Effects with Other Respirable Particles', International Journal of Environmental Research and Public Health, (6), pp. 445-462. doi: $10.3390 /$ ijerph6020445.

2. Permenkes RI (2012) Pengamanan Bahan yang Mengandung Zat Adiktif Berupa Produk Tembakau Bagi Kesehatan.

3. Wojtunik, K. A. Ciesla, L. M. and Waksmundzka-hajnos, M. (2014) 'Model Studies on the Antioxidant Activity of Common Terpenoid Constituents of Essential Oils by Means of the 2,2-Diphenyl-1- picrylhydrazyl Method'

4. Swamy, M. K. and Sinniah, U. R. (2015) 'A Comprehensive Review on the Phytochemical Constituents and Pharmacological Activities of Pogostemon cablin Benth.':, Molecules, 20, pp. 8521-8547. doi: $10.3390 /$ molecules20058521

5. Dechayont, B. et al. (2017) 'Antioxidant and Antimicrobial Activities of Pogostemon cablin ( Blanco ) Benth .', Hindawi Journal of Botany, 2017, p. 6.

6. Ayala, A., Munoz, M.F. and Arguelles, S. (2014) 'Lipid Peroxidation: Production, Metabolism, and Signaling Mechanisms of Malondialdehyde and 4-Hydroxy-2-Nonenal', Oxidative Medicine and Cellular Longevity, 2014, p. 31. doi: $10.1155 / 2014 / 360438$

7. Lü, J.-M. et al. (2010) 'Chemical and molecular mechanisms of antioxidants: experimental approaches and model systems.', Journal of cellular and molecular medicine, 14(4), pp. 840-60. doi: 10.1111/j.15824934.2009.00897.x

8. Balitro. (2008) 'pengawas benih tanaman.blogspot.com/2008/07/halyang-perlu-anda-ketahui-tentang.html

9. Kementrian Kesehatan RI (2012) Data dan Informasi Kesehatan Penyakit Tidak Menular. II.

10. Pratiwi, S. R. et al. (2018) 'Asupan Vitamin C dan E dengan SQ-FFQ terhadap Fungsi Paru Perokok', MKMI, 14(2), pp. 101-107.

11. Upadhyaya, K. et al. (2009) 'Terpenoid Composition and Antioxidant Activity of Essential Oil from Leaves of Salvia leucantha Cav.', Jeobp, 12(5), pp. 551-556. 